\title{
Vitamin D-binding protein controls T cell responses to vitamin $D$
}

\author{
Martin Kongsbak ${ }^{1 \dagger}$, Marina Rode von Essen ${ }^{1 \dagger}$, Trine Bøegh Levring ${ }^{1}$, Peter Schjerling ${ }^{2,3}$, Anders Woetmann ${ }^{1}$, \\ Niels Ødum', Charlotte Menné Bonefeld ${ }^{1}$ and Carsten Geisler ${ }^{1 *}$
}

\begin{abstract}
Background: In vitro studies have shown that the active form of vitamin $\mathrm{D}_{3}, 1 \mathrm{a}, 25$-dihydroxyvitamin $\mathrm{D} 3\left(1,25(\mathrm{OH})_{2} \mathrm{D}_{3}\right)$, can regulate differentiation of $\mathrm{CD} 4^{+} \mathrm{T}$ cells by inhibiting Th1 and Th17 cell differentiation and promoting Th2 and Treg cell differentiation. However, the serum concentration of $1,25(\mathrm{OH})_{2} \mathrm{D}_{3}$ is far below the effective concentration of 1,25 $(\mathrm{OH})_{2} \mathrm{D}_{3}$ found in in vitro studies, and it has been suggested that $1,25(\mathrm{OH})_{2} \mathrm{D}_{3}$ must be produced locally from the inactive precursor 25 -hydroxyvitamin $\mathrm{D} 3\left(25(\mathrm{OH}) \mathrm{D}_{3}\right)$ to affect ongoing immune responses in vivo. Although it has been reported that activated T cells express the $25(\mathrm{OH}) \mathrm{D}$-1 a-hydroxylase CYP27B1 that converts $25(\mathrm{OH}) \mathrm{D}_{3}$ to $1,25(\mathrm{OH})_{2} \mathrm{D}_{3}$, it is still controversial whether activated $T$ cells have the capacity to produce sufficient amounts of $1,25(\mathrm{OH})_{2} \mathrm{D}_{3}$ to affect vitamin D-responsive genes. Furthermore, it is not known how the vitamin D-binding protein (DBP) found in high concentrations in serum affects $T$ cell responses to $25(\mathrm{OH}) \mathrm{D}_{3}$.

Results: We found that activated T cells express CYP27B1 and have the capacity to produce sufficient $1,25(\mathrm{OH})_{2} \mathrm{D}_{3}$ to affect vitamin D-responsive genes when cultured with physiological concentrations of $25(\mathrm{OH}) \mathrm{D}_{3}$ in serum-free medium. However, if the medium was supplemented with serum or purified DBP, DBP strictly inhibited the production of 1,25 $(\mathrm{OH})_{2} \mathrm{D}_{3}$ and $25(\mathrm{OH}) \mathrm{D}_{3}$-induced T cell responses. In contrast, DBP did not inhibit the effect of exogenous $1,25(\mathrm{OH})_{2} \mathrm{D}_{3}$. Actin, arachidonic acid and albumin did not affect the sequestration of $25(\mathrm{OH}) \mathrm{D}_{3}$ by $\mathrm{DBP}$, whereas carbonylation of DBP did.

Conclusions: Activated T cells express CYP27B1 and can convert $25(\mathrm{OH}) \mathrm{D}_{3}$ to $1,25(\mathrm{OH})_{2} \mathrm{D}_{3}$ in sufficiently high concentrations to affect vitamin D-responsive genes when cultured in serum-free medium. However, DBP sequesters $25(\mathrm{OH}) \mathrm{D}_{3}$ and inhibits the production of $1,25(\mathrm{OH})_{2} \mathrm{D}_{3}$ in $\mathrm{T}$ cells. To fully exploit the immune-regulatory potential of vitamin $\mathrm{D}$, future studies of the mechanisms that enable the immune system to exploit $25(\mathrm{OH}) \mathrm{D}_{3}$ and convert it to $1,25(\mathrm{OH})_{2} \mathrm{D}_{3}$ in vivo are required.
\end{abstract}

Keywords: T cells, T cell activation, Vitamin D, Vitamin D-binding protein, CYP27B1, Megalin, Cubilin

\section{Background}

Following antigen recognition $\mathrm{CD}_{4}^{+} \mathrm{T}$ cells differentiate into one of several types of Th cells including Th1, Th2, Th17 and Treg cells that secrete distinct sets of cytokines [1-3]. Studies have suggested that, in addition to the cytokine milieu, vitamin $\mathrm{D}$ is an important determinant in this differentiation of $\mathrm{CD}^{+}{ }^{+} \mathrm{T}$ cells [4]. Thus, in vitro studies have shown that the active form of vitamin $D_{3}, 1 \alpha, 25$ -

\footnotetext{
* Correspondence: cge@sund.ku.dk

${ }^{\dagger}$ Equal contributors

'Department of International Health, Immunology and Microbiology, Faculty of Health and Medical Sciences, University of Copenhagen, Copenhagen, Denmark

Full list of author information is available at the end of the article
}

dihydroxyvitamin D3 $\left(1,25(\mathrm{OH})_{2} \mathrm{D}_{3}\right)$, inhibits production of IFN- $\gamma$ and augment the production of IL-4, thereby limiting Th1 and promoting Th2 cell differentiation [5-9]. Furthermore, $1,25(\mathrm{OH})_{2} \mathrm{D}_{3}$ inhibits Th17 cell differentiation and induces differentiation of Treg cells [10-12]. It is therefore generally believed that vitamin D plays an antiinflammatory role, and accordingly vitamin D deficiency has been associated with increased risk of autoimmune diseases such as type 1 diabetes mellitus [13], lupus erythematosus [14] and multiple sclerosis $[15,16]$.

25-hydroxyvitamin D3 $\left(25(\mathrm{OH}) \mathrm{D}_{3}\right)$ is the inactive precursor of $1,25(\mathrm{OH})_{2} \mathrm{D}_{3}$ and is considered the best parameter for evaluation of the vitamin $\mathrm{D}$ status of a subject. The normal range of serum $25(\mathrm{OH}) \mathrm{D}_{3}$ concentrations is 
25-170 nM [17]. The serum concentration of the active $1,25(\mathrm{OH})_{2} \mathrm{D}_{3}$ is approximately 1000 -fold lower (60-110 pM) and far below the effective concentration of 1,25 $(\mathrm{OH})_{2} \mathrm{D}_{3}$ found in in vitro studies. Thus, in most in vitro studies more than a 100-fold higher concentration of 1,25 $(\mathrm{OH})_{2} \mathrm{D}_{3}$ than found in serum is often required to obtain an effect $[7,10-12,18,19]$. It has therefore been suggested that the level of circulating $1,25(\mathrm{OH})_{2} \mathrm{D}_{3}$ is too low to affect immune responses in vivo, and that sufficient levels are obtained by local conversion of $25(\mathrm{OH}) \mathrm{D}_{3}$ to 1,25 $(\mathrm{OH})_{2} \mathrm{D}_{3}$ [20]. In accordance, it has been shown that activated antigen presenting cells (APC) express the $25(\mathrm{OH})$ D-1 $\alpha$-hydroxylase CYP27B1 that converts $25(\mathrm{OH}) \mathrm{D}_{3}$ to $1,25(\mathrm{OH})_{2} \mathrm{D}_{3}$, and that $\mathrm{APC}$ can produce $1,25(\mathrm{OH})_{2} \mathrm{D}_{3}$ from $25(\mathrm{OH}) \mathrm{D}_{3}$ in vitro and respond to this through the vitamin D receptor (VDR) in an autocrine fashion [20-23]. Elevated levels of $1,25(\mathrm{OH})_{2} \mathrm{D}_{3}$ in association with hypercalcemia have been observed in patients with sarcoidosis, tuberculosis, and other infections and inflammatory diseases in which the pathology is characterized by granuloma formation [24], supporting the hypothesis that activated macrophages can produce significant amounts of $1,25(\mathrm{OH})$ ${ }_{2} \mathrm{D}_{3}$ in vivo.

Like APC, activated T cells express the VDR and CYP27B1 [20,21,25-29]. However, whether $\mathrm{T}$ cells can convert $25(\mathrm{OH}) \mathrm{D}_{3}$ to $1,25(\mathrm{OH})_{2} \mathrm{D}_{3}$ in physiological relevant concentrations and respond to this in an autocrine fashion is a matter of debate. Most studies on the effect of vitamin $\mathrm{D}$ on $\mathrm{T}$ cells have not addressed this question as they investigated the direct effects of supra-physiological concentrations of $1,25(\mathrm{OH})_{2} \mathrm{D}_{3}$ and not how $25(\mathrm{OH}) \mathrm{D}_{3}$ affects $\mathrm{T}$ cell responses. One study has shown that isolated $\mathrm{T}$ cells have the ability to convert $25(\mathrm{OH}) \mathrm{D}_{3}$ to $1,25(\mathrm{OH})$ ${ }_{2} \mathrm{D}_{3}$ in concentrations that actually affects vitamin $\mathrm{D}$ responsive genes in an autocrine fashion [21]. In agreement, we recently found that purified $\mathrm{CD}^{+} \mathrm{T}$ cells have the ability to produce substantial amounts of $1,25(\mathrm{OH})_{2} \mathrm{D}_{3}$ when activated in the presence of $25(\mathrm{OH}) \mathrm{D}_{3}$ [27]. In contrast, another recent study found that although activated $\mathrm{T}$ cells do express CYP27B1, the expression level is not sufficiently high to allow production of $1,25(\mathrm{OH})_{2} \mathrm{D}_{3}$ in concentrations that affect vitamin $\mathrm{D}$-responsive genes [20]. The authors found that $25(\mathrm{OH}) \mathrm{D}_{3}$ only affected $\mathrm{T}$ cell responses when APC were present, and suggested that APC locally secrete sufficient amounts of $1,25(\mathrm{OH})_{2} \mathrm{D}_{3}$ to directly influence the surrounding $\mathrm{T}$ cells in a paracrine fashion.

Other important players influencing the bioavailable levels of vitamin $\mathrm{D}$ are the vitamin $\mathrm{D}$-binding protein (DBP) and albumin. $25(\mathrm{OH}) \mathrm{D}_{3}$ and $1,25(\mathrm{OH})_{2} \mathrm{D}_{3}$ circulate bound to DBP (85-90\%) and albumin (10-15\%) with less than $1 \%$ in their free form [30,31]. Studies of DBP knock-out mice have shown that DBP acts as a vitamin $\mathrm{D}$ reservoir by protecting $25(\mathrm{OH}) \mathrm{D}_{3}$ and 1,25
$(\mathrm{OH})_{2} \mathrm{D}_{3}$ from degradation and renal secretion [32]. However, DBP also sequesters $25(\mathrm{OH}) \mathrm{D}_{3}$ and $1,25(\mathrm{OH})$ ${ }_{2} \mathrm{D}_{3}$ and inhibits their action on monocytes, DC and keratinocytes in vitro $[20,33,34]$. How DBP affects T cell responses to $25(\mathrm{OH}) \mathrm{D}_{3}$ still needs to be determined.

The objectives of this study were to further elucidate whether $\mathrm{T}$ cells have the ability to convert $25(\mathrm{OH}) \mathrm{D}_{3}$ to $1,25(\mathrm{OH})_{2} \mathrm{D}_{3}$ in proportions that affect a panel of vitamin D-responsive genes in an autocrine fashion and to investigate how $\mathrm{DBP}$ regulates $\mathrm{T}$ cell responses to 25 $(\mathrm{OH}) \mathrm{D}_{3}$.

\section{Results}

Activated T cells express CYP27B1 and have the capacity to convert $25(\mathrm{OH}) \mathrm{D}_{3}$ to $1,25(\mathrm{OH})_{2} \mathrm{D}_{3}$

In order to convert $25(\mathrm{OH}) \mathrm{D}_{3}$ to $1,25(\mathrm{OH})_{2} \mathrm{D}_{3}$ cells must express the $25(\mathrm{OH}) \mathrm{D}-1 \alpha$-hydroxylase CYP27B1. To determine whether naïve $\mathrm{CD}^{+} \mathrm{T}$ cells express CYP27B1, we purified $\mathrm{CD}_{45 \mathrm{RA}^{+} \mathrm{CD} 4}{ }^{+}$cells from the blood of healthy donors. The resulting cell population contained 95-98\% $\mathrm{CD}^{+} \mathrm{T}$ cells of which more than $96 \%$ were CD45RA ${ }^{+}$ (Additional file 1: Figure S1). The purified cells were stimulated with $\mathrm{CD} 3 / \mathrm{CD} 28$ beads for 0-5 days in serum-free medium and their expression of CYP27B1 mRNA was subsequently measured. We found that naïve $\mathrm{CD} 4^{+} \mathrm{T}$ cells express no or very low levels of CYP27B1. However, the cells started to express CYP27B1 mRNA shortly after stimulation, and the expression peaked after 2-3 days of stimulation (Figure 1A). These results suggested that activated human $\mathrm{CD} 4^{+} \mathrm{T}$ cells have the capacity to convert 25 $(\mathrm{OH}) \mathrm{D}_{3}$ to $1,25(\mathrm{OH})_{2} \mathrm{D}_{3}$. To validate this, we stimulated purified $\mathrm{CD}^{+}{ }^{+} \mathrm{T}$ cells in the presence of $100 \mathrm{nM} 25(\mathrm{OH})$ $\mathrm{D}_{3}$ corresponding to physiological concentrations of 25 $(\mathrm{OH}) \mathrm{D}_{3}$ in serum and then measured the production of $1,25(\mathrm{OH})_{2} \mathrm{D}_{3}$. We found that activated $\mathrm{CD}^{+} \mathrm{T}$ cells produced $1,25(\mathrm{OH})_{2} \mathrm{D}_{3}$ with a kinetic similar to the kinetics of CYP27B1 expression in the cells, and that the production peaked after 3 days of stimulation (Figure 1B). Finally, to determine whether the cells expressed the receptor for $1,25(\mathrm{OH})_{2} \mathrm{D}_{3}$, we determined the expression of the VDR in $\mathrm{CD}^{+} \mathrm{T}$ cells stimulated for $0-5$ days. We found that VDR expression peaked simultaneously with the peak production of $1,25(\mathrm{OH})_{2} \mathrm{D}_{3}$ at day 3 (Figure $1 \mathrm{C}$ ). Taken together, these experiments demonstrated that activated human $\mathrm{CD}^{+}{ }^{+} \mathrm{T}$ cells express CYP27B1, that they have the capacity to convert $25(\mathrm{OH}) \mathrm{D}_{3}$ at physiological concentrations to the active $1,25(\mathrm{OH})_{2} \mathrm{D}_{3}$, and that they express the receptor for $1,25(\mathrm{OH})_{2} \mathrm{D}_{3}$.

Activated T cells have the ability to produce $1,25(\mathrm{OH})_{2} \mathrm{D}_{3}$ in sufficiently high concentrations to affect vitamin D-responsive genes

Having demonstrated that activated $\mathrm{CD}^{+}{ }^{+} \mathrm{T}$ cells have the capacity to produce the active form of vitamin $D$ 


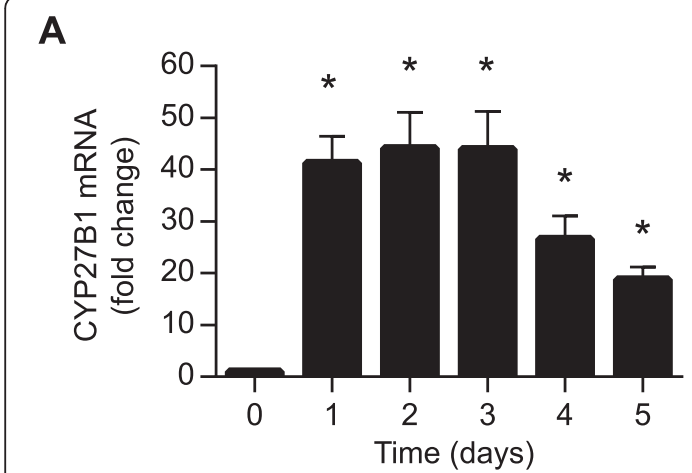

B

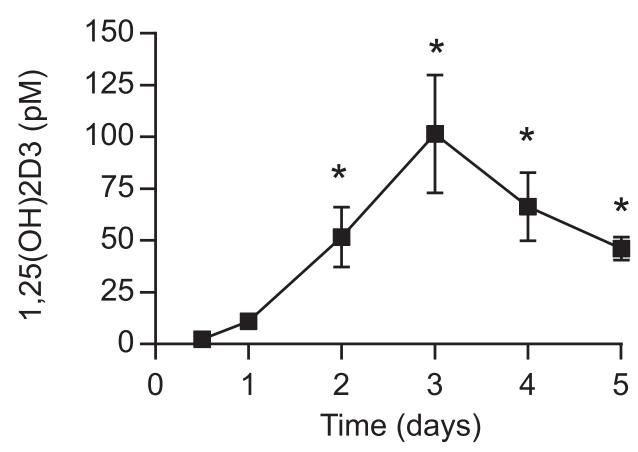

C

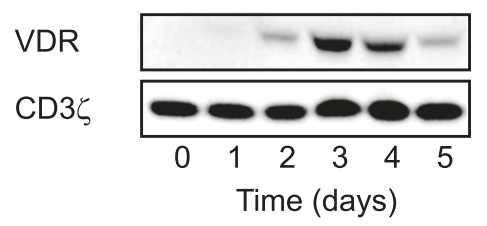

Figure 1 Activated T cells express CYP27B1 and have the capacity to convert $25(\mathrm{OH}) \mathrm{D}_{3}$ to $\mathbf{1 , 2 5}(\mathrm{OH})_{2} \mathrm{D}_{3}$. (A) Relative CYP27B1 mRNA expression in T cells activated for $0-5$ days normalized to CYP27B1 expression in naïve $T$ cells. Values are given as mean + SEM from 3 independent experiments, ${ }^{*} p<0.05$. (B) $1,25(\mathrm{OH})_{2} \mathrm{D}_{3}$ in the medium of $T$ cells activated for $0-5$ days in the presence of $100 \mathrm{nM} 25(\mathrm{OH}) \mathrm{D}_{3}$. Data are given as mean \pm SEM from 3 independent experiments, ${ }^{*} p<0.05$. (C) Representative Western blot of VDR and CD3Z (loading control) expression in $T$ cells activated for $0-5$ days.

and that they simultaneously express the VDR, we next asked whether the production of $1,25(\mathrm{OH})_{2} \mathrm{D}_{3}$ was sufficiently high to induce autocrine activation of vitamin Dresponsive genes. To study this, we took advantage of the finding that the cell surface expression levels of $\mathrm{CD} 38$ on activated $\mathrm{T}$ cells are dependent on the concentration of $1,25(\mathrm{OH})_{2} \mathrm{D}_{3}$ present during $\mathrm{T}$ cell activation $[12,35]$. Consequently, we activated $\mathrm{CD}^{+} \mathrm{T}$ cells in serum-free medium in the presence of increasing concentrations of $25(\mathrm{OH}) \mathrm{D}_{3}$ or $1,25(\mathrm{OH})_{2} \mathrm{D}_{3}$ and then measured CD38 expression at day 3. In accordance with previous studies, we found that $1,25(\mathrm{OH})_{2} \mathrm{D}_{3}$ significantly up-regulated CD38 expression in activated T cells in a dose-dependent manner (Figure 2A) [12,35]. In addition, we found that $25(\mathrm{OH}) \mathrm{D}_{3}$ also induced CD38 up-regulation, suggesting that activated $\mathrm{T}$ cells can produce sufficiently high concentrations of $1,25(\mathrm{OH})_{2} \mathrm{D}_{3}$ to affect vitamin D-responsive genes (Figure 2A). We noted that whereas $25(\mathrm{OH}) \mathrm{D}_{3}$ at a physiological concentration of $100 \mathrm{nM}$ induced maximum CD38 up-regulation, 1,25 $(\mathrm{OH})_{2} \mathrm{D}_{3}$ was required at a 100 -fold higher concentration $(10 \mathrm{nM})$ than physiological levels $(60-110 \mathrm{pM})$ to induce the same effect. That a supra-physiological concentration of $1,25(\mathrm{OH})_{2} \mathrm{D}_{3}$ was required to obtain an effect in our study is in good line with previous studies $[7,10-12,18,19]$. However, in contrast to our observations that $25(\mathrm{OH}) \mathrm{D}_{3}$ at $100 \mathrm{nM}$ had a clear effect on T cells, most previous studies on $25(\mathrm{OH}) \mathrm{D}_{3}$ required at least a 100 -fold higher concentration of $25(\mathrm{OH}) \mathrm{D}_{3}$ than found in serum to induce an effect [21]. One explanation for this discrepancy could be that whereas our experiments were performed in serum-free medium most previous studies have been performed in medium supplemented with serum. To study whether the presence of serum could explain the discrepancy between the concentrations of $25(\mathrm{OH}) \mathrm{D}_{3}$ required to obtain an effect on $\mathrm{T}$ cells, we activated $\mathrm{CD} 4^{+} \mathrm{T}$ cells in the presence of increasing concentrations of $25(\mathrm{OH}) \mathrm{D}_{3}$ and $1,25(\mathrm{OH})_{2} \mathrm{D}_{3}$ in medium supplemented with $5 \%$ fetal bovine serum (FBS) and measured CD38 expression at day 3. We found that the presence of serum significantly shifted the concentration of $25(\mathrm{OH}) \mathrm{D}_{3}$ required to induce $\mathrm{CD} 38$ expression (Figure 2B). Thus, compared to serum-free medium approximately 100 -fold higher concentrations of $25(\mathrm{OH})$ $\mathrm{D}_{3}$ were required to induce a similar effect on CD38 expression in T cells cultured in medium supplemented with serum. In contrast, the presence of serum did not significantly shift the concentration of $1,25(\mathrm{OH})_{2} \mathrm{D}_{3}$ required to induce CD38 expression. To separately analyse the role of DBP and albumin in this serum-mediated inhibition of the effect of $25(\mathrm{OH}) \mathrm{D}_{3}$ on T cells, we activated $\mathrm{CD}^{+} \mathrm{T}$ cells in the presence of $100 \mathrm{nM} 25(\mathrm{OH}) \mathrm{D}_{3}$ in serum-free medium supplemented with increasing concentrations of either DBP or albumin and measured CD38 expression at day 3. We found that DBP at concentrations above 250$500 \mathrm{nM}$ completely abolished the effect of $25(\mathrm{OH}) \mathrm{D}_{3}$ on CD38 expression, whereas albumin did not affect the effect of $25(\mathrm{OH}) \mathrm{D}_{3}$ (Figure $2 \mathrm{C}$ and $\mathrm{D}$ ).

Although $\mathrm{T}$ cells converted $25(\mathrm{OH}) \mathrm{D}_{3}$ to $1,25(\mathrm{OH})$ ${ }_{2} \mathrm{D}_{3}$ when activated in serum-free medium, we could not exclude the possibility that the observed $25(\mathrm{OH})$ $\mathrm{D}_{3}$-induced up-regulation of CD38 was caused directly by $25(\mathrm{OH}) \mathrm{D}_{3}$ and not by $1,25(\mathrm{OH})_{2} \mathrm{D}_{3}$. To exclude this possibility, we determined the effect of the CYP27B1 inhibitor ketoconazole on CD38 up-regulation. We activated $\mathrm{T}$ cells in the absence or presence of ketoconazole and increasing concentrations of $25(\mathrm{OH}) \mathrm{D}_{3}$. We 
A

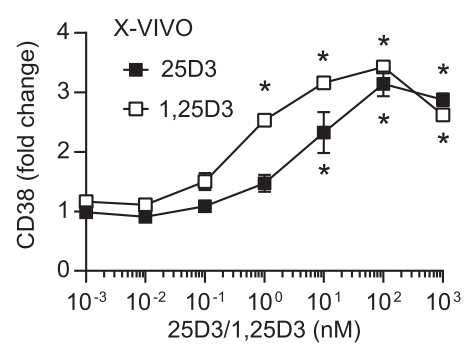

C

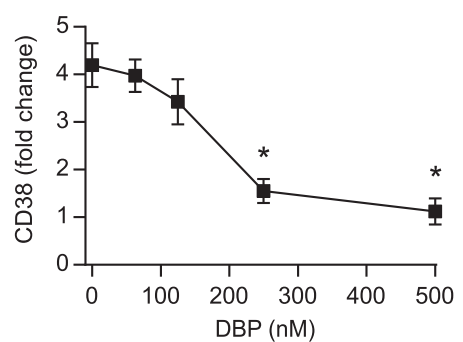

E

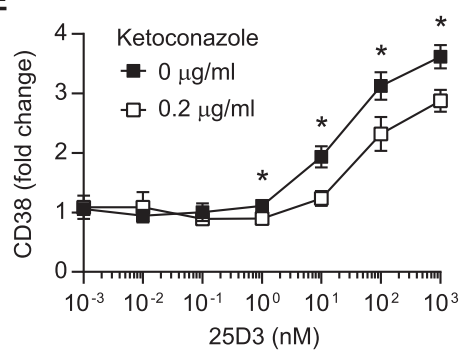

B

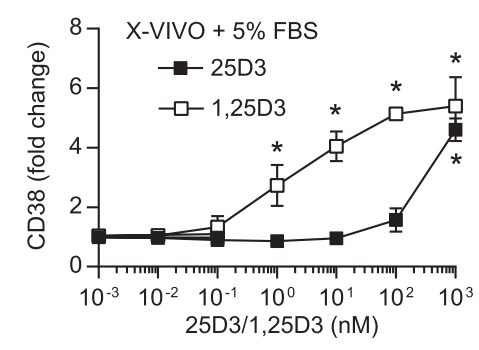

D

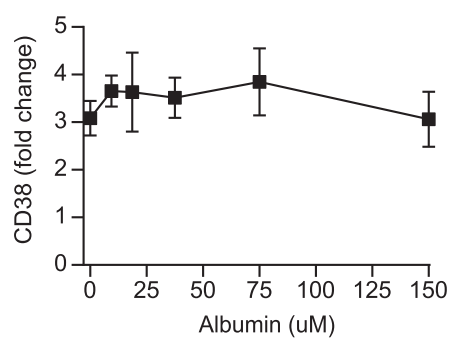

$\mathbf{F}$

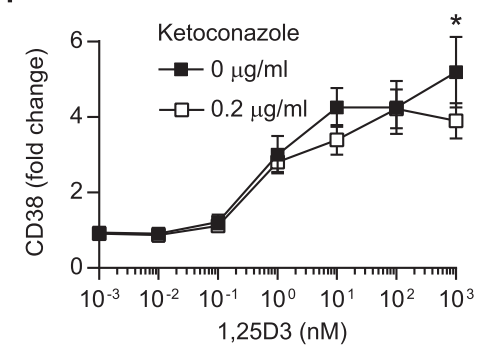

Figure 2 In the absence of serum activated T cells can produce 1,25(OH) ${ }_{2} \mathrm{D}_{3}$ in concentrations that affect CD38 expression. Relative CD38 cell surface expression on T cells activated for 3 days in X-VIVO 15 (A) or X-VIVO 15 supplemented with 5\% FBS (B) in the presence of the indicated concentrations of $25(\mathrm{OH}) \mathrm{D}_{3}$ and $1,25(\mathrm{OH})_{2} \mathrm{D}_{3}$ normalized to $\mathrm{CD} 38$ cell surface expression on $\mathrm{T}$ cells activated in the absence of $25(\mathrm{OH})$ $\mathrm{D}_{3}$ and $1,25(\mathrm{OH})_{2} \mathrm{D}_{3}$. Relative CD38 cell surface expression on T cells activated for 3 days in X-VIVO 15 medium supplemented with increasing concentrations of DBP (C) or albumin (D) in the presence of $100 \mathrm{nM} 25(\mathrm{OH}) \mathrm{D}_{3}$ normalized to $C D 38$ cell surface expression on $T$ cells activated in the absence of $25(\mathrm{OH}) \mathrm{D}_{3}$. Relative $\mathrm{CD} 38$ cell surface expression on T cells activated for 3 days in the absence or presence of ketoconazole and the indicated concentrations of $25(\mathrm{OH}) \mathrm{D}_{3} \mathbf{( E )}$ or $1,25(\mathrm{OH})_{2} \mathrm{D}_{3} \mathbf{( F )}$ normalized to $\mathrm{CD} 38$ cell surface expression on $T$ cells activated in the absence of $25(\mathrm{OH}) \mathrm{D}_{3}$ or $1,25(\mathrm{OH})_{2} \mathrm{D}_{3}$. (A-F) Mean values \pm SEM from 3 independent experiments are plotted, ${ }^{*} \mathrm{p}<0.05$.

found that ketoconazole efficiently inhibited $25(\mathrm{OH}) \mathrm{D}_{3}$-induced CD38 up-regulation (Figure 2E). These observations indicated that conversion of $25(\mathrm{OH}) \mathrm{D}_{3}$ to $1,25(\mathrm{OH})_{2} \mathrm{D}_{3}$ is required for $25(\mathrm{OH}) \mathrm{D}_{3}$-induced $\mathrm{CD} 38$ up-regulation. If this is the case and ketoconazole does not in itself influence CD38 expression then ketoconazole should not affect $1,25(\mathrm{OH})_{2} \mathrm{D}_{3}$-induced CD38 up-regulation. Consequently, we activated $\mathrm{T}$ cells in the absence or presence of ketoconazole and increasing concentrations of $1,25(\mathrm{OH})_{2} \mathrm{D}_{3}$. We found that ketoconazole did not affect $1,25(\mathrm{OH})_{2} \mathrm{D}_{3}$-induced CD38 up-regulation (Figure 2F). These experiments indicated that it is not $25(\mathrm{OH}) \mathrm{D}_{3}$ itself that induces CD38 up-regulation, but that the conversion of $25(\mathrm{OH}) \mathrm{D}_{3}$ to 1,25 $(\mathrm{OH})_{2} \mathrm{D}_{3}$ is required for $25(\mathrm{OH}) \mathrm{D}_{3}$-induced $\mathrm{CD} 38$ upregulation.

Thus, we could conclude that activated $\mathrm{T}$ cells have the capacity to produce sufficient $1,25(\mathrm{OH})_{2} \mathrm{D}_{3}$ to affect vitamin D-responsive genes as measured by CD38 expression when cultured with physiological concentrations of $25(\mathrm{OH}) \mathrm{D}_{3}$ in serum-free medium. However, addition of DBP to the medium inhibited the effect of $25(\mathrm{OH}) \mathrm{D}_{3}$. In contrast, DBP did not seem to affect the concentration of $1,25(\mathrm{OH})_{2} \mathrm{D}_{3}$ required to regulate vitamin D-responsive genes.

\section{DBP inhibits $25(\mathrm{OH}) \mathrm{D}_{3}$-induced $\mathrm{T}$ cell responses}

To determine whether the inhibitory effect of DBP on $25(\mathrm{OH}) \mathrm{D}_{3}$ was limited to $\mathrm{CD} 38$ gene expression or was a general phenomenon for vitamin $\mathrm{D}$-responsive genes in $\mathrm{T}$ cells, we studied the influence of $25(\mathrm{OH}) \mathrm{D}_{3}$ and DBP alone or in combination on the expression of molecules known to be encoded by vitamin D-responsive genes such as CTLA-4 [7,20], PLC- $\gamma 1$ [25,36], IL-13 [37] and IFN- $\gamma$ [7] in addition to CD38 [35]. We stimulated 
$\mathrm{CD}_{4}^{+} \mathrm{T}$ cells for 3 days in serum-free medium or serum-free medium supplemented with either $25(\mathrm{OH}) \mathrm{D}_{3}$ or DBP alone or $25(\mathrm{OH}) \mathrm{D}_{3}$ plus DBP. We confirmed that $25(\mathrm{OH}) \mathrm{D}_{3}$ up-regulates $\mathrm{CD} 38 \mathrm{mRNA}$ and protein in activated $\mathrm{T}$ cells, and that this up-regulation is completely inhibited by DBP (Figure 3A and B). Likewise, we found that the $25(\mathrm{OH}) \mathrm{D}_{3}$-induced up-regulation of CTLA-4, PLC- $\gamma 1$ and IL-13 and down-regulation of IFN- $\gamma$ was abolished by DBP (Figure $3 \mathrm{C}-\mathrm{H}$ ). Thus, DBP generally inhibits the effect of $25(\mathrm{OH}) \mathrm{D}_{3}$ on vitamin $\mathrm{D}$ responsive genes in $\mathrm{T}$ cells. To further elucidate the underlying mechanism behind the inhibition of $25(\mathrm{OH})$ $\mathrm{D}_{3}$ in $\mathrm{T}$ cells mediated by DBP, we measured the production of active $1,25(\mathrm{OH})_{2} \mathrm{D}_{3}$ in the medium from the cultures described above. We found that in the presence of $25(\mathrm{OH}) \mathrm{D}_{3}$ activated $\mathrm{T}$ cells produced significant amounts of $1,25(\mathrm{OH})_{2} \mathrm{D}_{3}$; however, addition of DBP completely abolished the production of $1,25(\mathrm{OH})_{2} \mathrm{D}_{3}$ (Figure 3I). Thus, we could conclude that DBP strongly constrains the effect of $25(\mathrm{OH}) \mathrm{D}_{3}$ on vitamin D-responsive genes in $\mathrm{T}$ cells by inhibiting the conversion of $25(\mathrm{OH}) \mathrm{D}_{3}$ to 1,25 $(\mathrm{OH})_{2} \mathrm{D}_{3}$.

\section{T cells take up DBP from the environment by macropinocytosis}

DBP is internalized by megalin-mediated endocytosis in kidney and mammary cells that express megalin and cubilin [38-40]. Megalin-mediated endocytosis of DBP facilitates uptake and conversion of $25(\mathrm{OH}) \mathrm{D}_{3}$ to $1,25(\mathrm{OH})_{2} \mathrm{D}_{3}$ in these types of cells $[39,40]$. To study whether T cells can take up DBP from the environment, we incubated naïve and activated T cells with DBP conjugated to Alexa Fluor 488 (DBP-AF488). Flow cytometry revealed increased fluorescence of activated $\mathrm{T}$ cells compared to naïve $\mathrm{T}$ cells, suggesting that activated $\mathrm{T}$ cells take up DBP-AF488 (Figure 4A). To exclude that the increased fluorescence simply was caused by DBP-AF488 adhering to the cell surface of the activated T cells as suggested in a

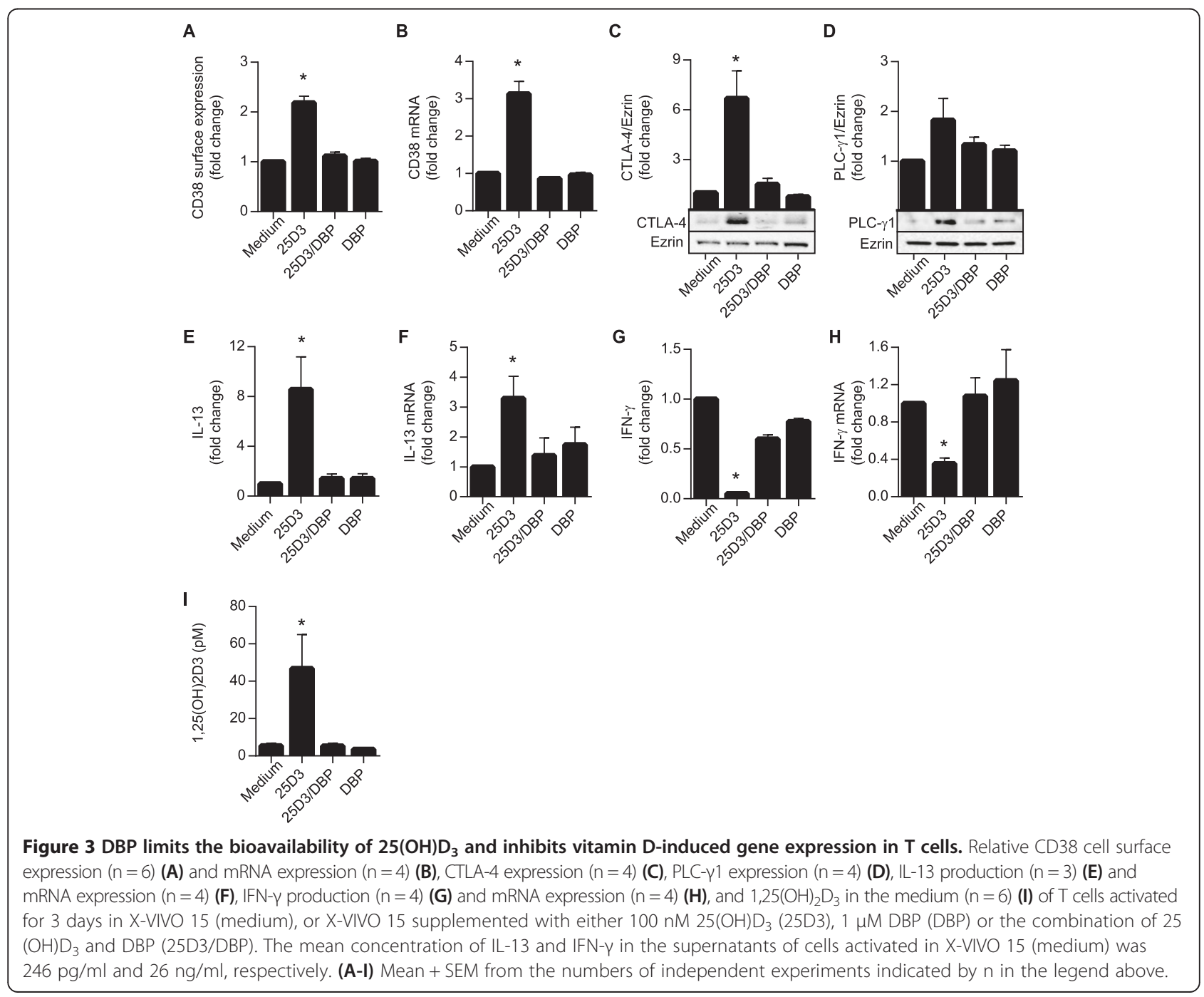




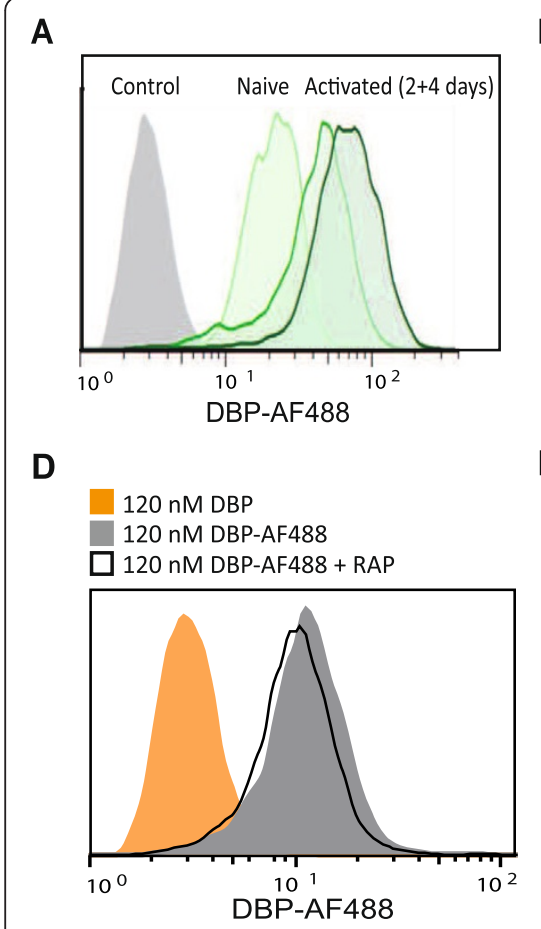

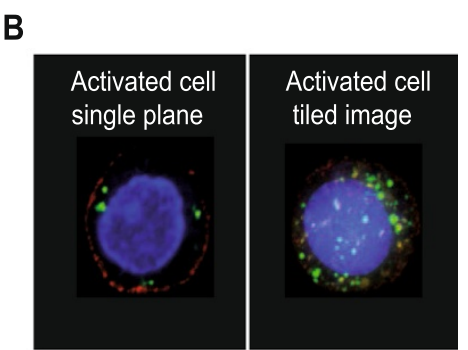

E

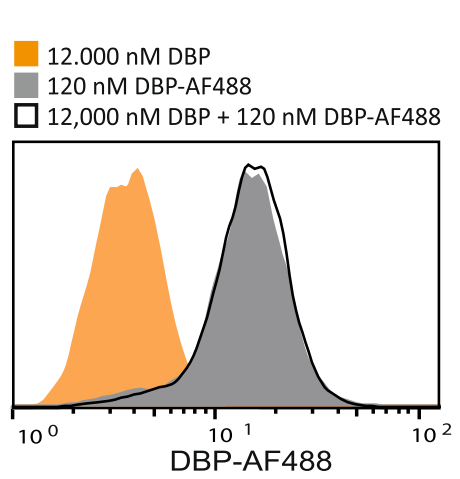

C

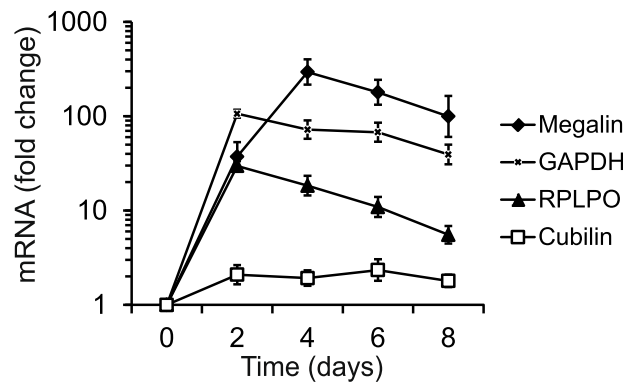

$\mathbf{F}$

$120 \mathrm{nM}$ DBP + DMSO

120 nM DBP-AF488 + DMSO

120 nM DBP-AF488 + $50 \mu \mathrm{M}$ EIPA

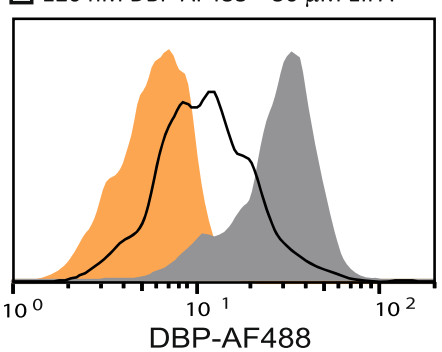

G

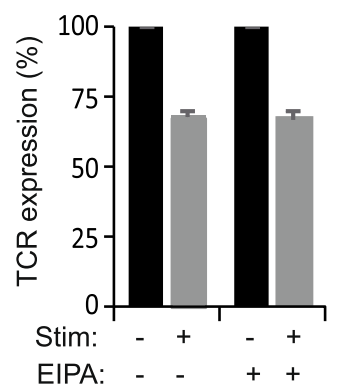

H

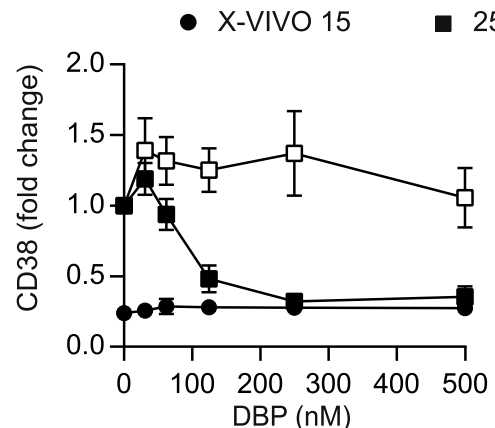

I

25(OH)D3

1,25(OH)2D3

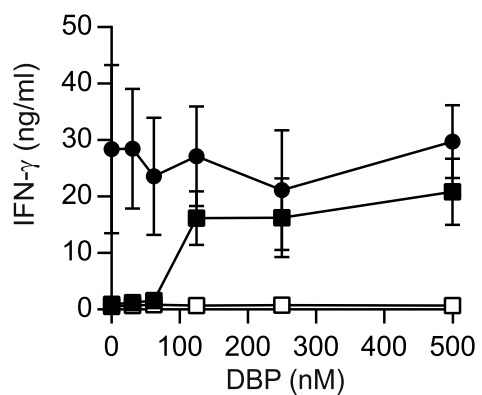

Figure $4 \mathrm{~T}$ cells take up DBP from the environment by macropinocytosis. (A) Representative flow cytometry histograms showing DBP-

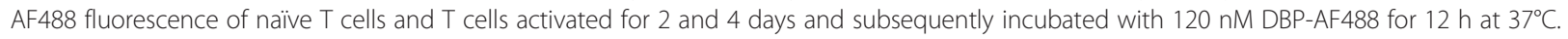
(B) Representative confocal microscopy images illustrating the uptake of DBP-AF488 in activated T cells. DBP-AF488 are shown in green; cell membrane (TCR) in red; nucleus in blue (DAPI stain). (C) Relative megalin, cubilin, GAPDH and RPLPO mRNA expression in T cells activated from 0-8 days normalized to the respective mRNA expression in naïve T cells. (D-F) Flow cytometry histograms illustrating DBP-AF488 fluorescence of activated T cells incubated with $120 \mathrm{nM}$ DBP-AF488 in the absence or presence of (D) RAP (1 $\mu \mathrm{M})$, (E) unlabelled DBP (12,000 nM), or (F) EIPA $(50 \mu \mathrm{M})$. (G) TCR internalization in activated T cells re-stimulated with $30 \mathrm{nM}$ PDBu for $60 \mathrm{~min}$ in the absence or presence of EIPA (50 $\mu \mathrm{M})$. TCR surface expression of non-stimulated cells was set to $100 \%$. (H-I) CD38 expression $\mathbf{( H )}$ and IFN- $\gamma$ production (I) of T cells activated for 3 days with the indicated concentrations of DBP in X-VIVO 15 and X-VIVO 15 supplemented with either 25(OH) $D_{3}(100 \mathrm{nM})$ or 1,25(OH) $2 \mathrm{D}_{3}(10 \mathrm{nM})$. (C, G-I) Data are shown as mean \pm SEM from 3 independent experiments.

previous study [41], we analysed the cells by confocal microscopy. We found that DBP-AF488 resided in small vesicles in the cytosol and could thus conclude that activated T cells actually take up DBP from the medium (Figure 4B). To determine whether this uptake might be mediated by megalin, we measured megalin and cubilin mRNA expression in naïve and activated $\mathrm{T}$ cells. Activated $\mathrm{T}$ cells up-regulated megalin mRNA to a level more than 100-fold higher than in naive $\mathrm{T}$ cells, whereas the cubilin mRNA levels were low in both naïve and activated $\mathrm{T}$ cells (Figure $4 \mathrm{C}$ ). In kidney and mammary cells megalin-mediated endocytosis of DBP is, in addition to megalin, dependent on the presence of cubilin at the cells surface $[38,40]$. To determine whether DBP was taken up by megalin-mediated endocytosis in activated $T$ cells despite their low expression of cubilin, we incubated cells with DBP-AF488 in the absence or presence of the megalin antagonist receptor-associated protein 
(RAP) as previously described $[33,38,39]$. We found that RAP did not influence DBP-AF488 uptake in the T cells (Figure 4D). Furthermore, blocking antibodies against megalin and calcium deprivation, known to inhibit megalin-mediated endocytosis [39], did not affect DBP uptake (Additional file 2: Figure S2). In line with this, high concentrations of DBP did not affect the uptake of DBP-AF488 (Figure 4E). Taken together these experiments indicated that DBP is not taken up by megalin-mediated endocytosis in T cells.

In addition to receptor-mediated endocytosis, cells can take up extracellular molecules by macropinocytosis. Macropinocytosis is characterized by its augmentation by cell activation and that it can be inhibited by amiloride $[42,43]$. We found that treatment of the cells with the amiloride analogue 5-(N-Ethyl- $\mathrm{N}$-isopropyl)-amiloride (EIPA) significantly inhibited uptake of DBP-AF488 (Figure 4F). To ensure that EIPA only blocked macropinocytosis and not receptor-mediated endocytosis, we measured the effect of EIPA on T cell receptor (TCR) internalization in parallel. TCR internalization is dependent on binding of the CD3y di-leucine based internalization motif to adaptor molecules of clathrin-coated pits $[44,45]$ and hence should not be influenced by EIPA. We found that EIPA did not affect TCR internalization (Figure 4G). Thus, we could conclude that DBP uptake by $\mathrm{CD}^{+}{ }^{+} \mathrm{T}$ cells is not mediated by megalin-mediated endocytosis but most likely by macropinocytosis.

Whereas megalin-mediated endocytosis of DBP facilitates uptake and conversion of $25(\mathrm{OH}) \mathrm{D}_{3}$ to $1,25(\mathrm{OH})$ ${ }_{2} \mathrm{D}_{3}$ in kidney and mammary cells $[39,40]$, macropinocytosis of DBP-25(OH)D $\mathrm{D}_{3}$ complexes did certainly not facilitate conversion of $25(\mathrm{OH}) \mathrm{D}_{3}$ to $1,25(\mathrm{OH})_{2} \mathrm{D}_{3}$ in $\mathrm{T}$ cells (Figure 3 ). To study whether DBP inhibited the effects of $1,25(\mathrm{OH})_{2} \mathrm{D}_{3}$ in the same way as it inhibited the effects of $25(\mathrm{OH}) \mathrm{D}_{3}$ on $\mathrm{T}$ cells, we stimulated $\mathrm{CD}_{4}{ }^{+} \mathrm{T}$ cells for 3 days in the presence of either $25(\mathrm{OH}) \mathrm{D}_{3}$ or $1,25(\mathrm{OH})_{2} \mathrm{D}_{3}$ and increasing concentrations of DBP. After 3 days we measured CD38 expression and IFN- $\gamma$ production. We found that in the absence of DBP both $25(\mathrm{OH}) \mathrm{D}_{3}$ and $1,25(\mathrm{OH})_{2} \mathrm{D}_{3}$ up-regulated CD38 expression and down-regulated IFN- $\gamma$ production. However, whereas addition of DBP clearly inhibited the effect of $25(\mathrm{OH}) \mathrm{D}_{3}$ it did not influence the effect of $1,25(\mathrm{OH})_{2} \mathrm{D}_{3}$ on $\mathrm{T}$ cell responses (Figure $4 \mathrm{H}$ and $\mathrm{I}$ ).

\section{Neither actin, arachidonic acid nor albumin affect the DBP-mediated inhibition of $25(\mathrm{OH}) \mathrm{D}_{3}$}

In addition to $25(\mathrm{OH}) \mathrm{D}_{3}$ and $1,25(\mathrm{OH})_{2} \mathrm{D}_{3}$, DBP can bind actin $[46,47]$ and fatty acids $[48,49]$. It has been suggested that binding of fatty acids to DBP decreases the affinity of $\mathrm{DBP}$ for $25(\mathrm{OH}) \mathrm{D}_{3}[48,49]$, and in theory this could increase the bioavailability of $25(\mathrm{OH}) \mathrm{D}_{3}$ for immune cells. To study whether binding of actin or arachidonic acid to DBP affected DBP-mediated inhibition of $25(\mathrm{OH}) \mathrm{D}_{3}$-induced $\mathrm{T}$ cell responses, we stimulated $\mathrm{CD}^{+} \mathrm{T}$ cells in the absence or presence of DBP plus $25(\mathrm{OH}) \mathrm{D}_{3}$ and increasing concentrations of actin or arachidonic acid. We found that neither actin nor arachidonic acid affected $25(\mathrm{OH}) \mathrm{D}_{3}$-induced $\mathrm{T}$ cell responses as measured by CD38 expression (Figure 5A and $\mathrm{B})$. Since albumin binds $25(\mathrm{OH}) \mathrm{D}_{3}$ with lower affinity than DBP, the ratio between DBP and albumin could in theory also affect the bioavailability of $25(\mathrm{OH}) \mathrm{D}_{3}$; however, as for actin and arachidonic acid we found that

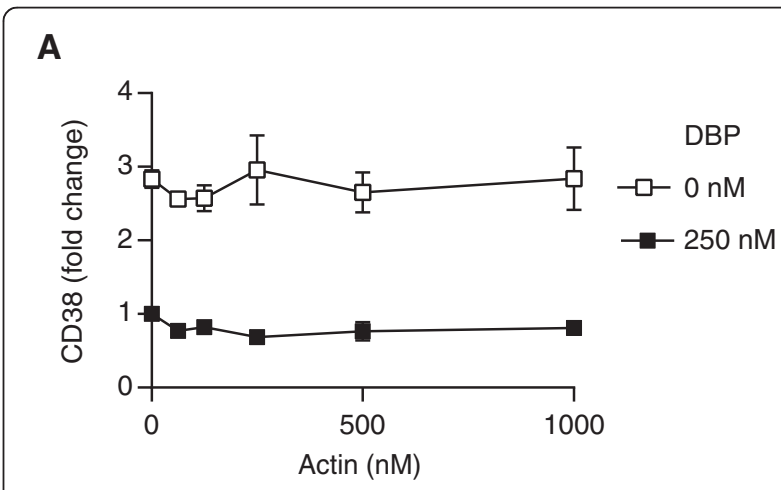

B

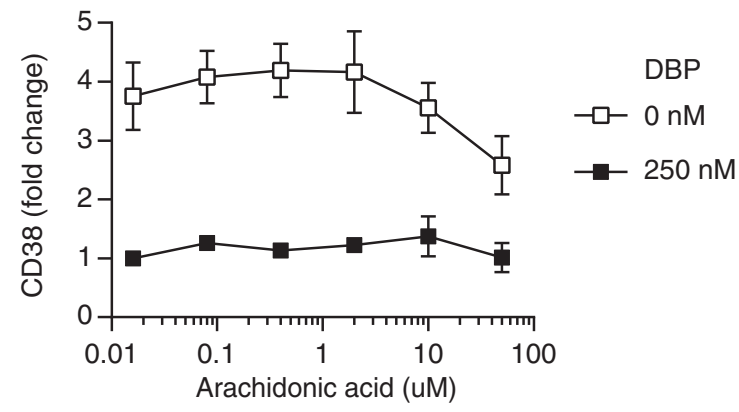

C

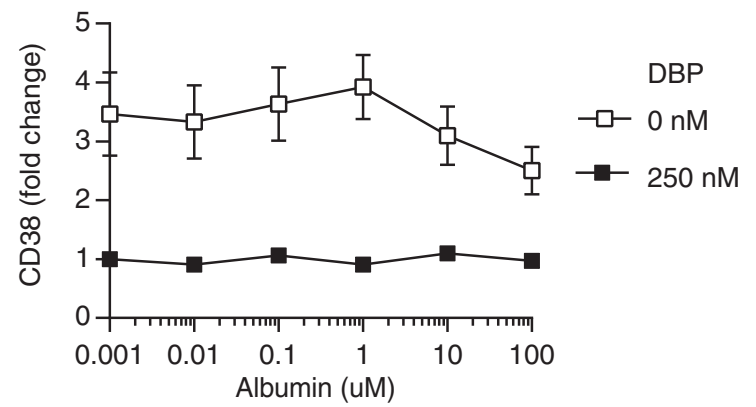

Figure 5 Neither actin, arachidonic acid or albumin increases the bioavailability of $\mathbf{2 5}(\mathrm{OH}) \mathrm{D}_{3}$ for T cells. Relative CD38 cell surface expression on $\mathrm{T}$ cells activated for 3 days in the presence of $25(\mathrm{OH}) \mathrm{D}_{3}(100 \mathrm{nM})$ and in the absence or presence of DBP (250 nM) and the indicated concentrations of (A) actin, (B) arachidonic acid or (C) albumin. Mean values \pm SEM from 3 independent experiments are plotted. 
albumin did not affect the DBP-mediated inhibition of $25(\mathrm{OH}) \mathrm{D}_{3}$-induced $\mathrm{T}$ cell responses (Figure $5 \mathrm{C}$ ).

\section{DBP carbonylation impedes DBP-mediated inhibition of $25(\mathrm{OH}) \mathrm{D}_{3}$-induced $\mathrm{T}$ cell responses}

The experiments above demonstrated that activated $\mathrm{T}$ cells have the capacity to convert $25(\mathrm{OH}) \mathrm{D}_{3}$ to $1,25(\mathrm{OH})$ ${ }_{2} \mathrm{D}_{3}$ given that $25(\mathrm{OH}) \mathrm{D}_{3}$ is available in a sufficiently high free concentration but that DBP normally binds and sequesters $25(\mathrm{OH}) \mathrm{D}_{3}$. The concentration of $\mathrm{DBP}$ relative to $25(\mathrm{OH}) \mathrm{D}_{3}$ determines the ratio of free to sequestered $25(\mathrm{OH}) \mathrm{D}_{3}$ [50]. The concentration of DBP in serum is approximately $5 \mu \mathrm{M}$, i.e. $50-100$ fold higher than the concentration of $25(\mathrm{OH}) \mathrm{D}_{3}$, and the free to sequestered ratio of $25(\mathrm{OH}) \mathrm{D}_{3}$ is very low [17,50,51]. However, primary immune responses are most often initiated in secondary lymphoid organs like lymph nodes where the concentration of DBP is unknown. It has been reported that the protein concentration in extracellular fluid/peripheral lymph might be as low as $5-10 \%$ of that found in serum [52,53], suggesting that the concentration of DBP in secondary lymphoid organs might be significantly lower than the concentration in serum. In agreement, by semi-quantitative analyses we found that the concentration of DBP in central lymph from minipigs was approximately $25 \%$ of the concentration of DBP in serum (Figure 6A).
Another mechanism that might decrease the concentration of functional DBP and thereby increase the availability of $25(\mathrm{OH}) \mathrm{D}_{3}$ is carbonylation of DBP. Carbonylation is a protein modification induced by oxidative stress [54], and increased carbonylation of serum proteins including DBP is seen during inflammatory responses [55-57]. Carbonylation of DBP could lead to a higher concentration of free $25(\mathrm{OH}) \mathrm{D}_{3}$ due to a reduced affinity of carbonylated DBP for 25(OH)D3 and/or increased degradation of DBP. To investigate this, we activated $\mathrm{CD}_{4}^{+} \mathrm{T}$ cells in the presence of $25(\mathrm{OH}) \mathrm{D}_{3}$ and increasing concentrations of either unmodified or carbonylated DBP (Figure 6B). We found that carbonylated DBP did not inhibit the effect of 25(OH) $\mathrm{D}_{3}$ to the same extent as unmodified DBP as measured by CD38 expression (Figure 6C). Thus, inflammation-induced carbonylation of DBP might contribute to an increased availability of $25(\mathrm{OH}) \mathrm{D}_{3}$ during an immune reaction.

Interestingly, we observed that a fraction of the nonoxidized purified human DBP was actually carbonylated (Figure 6B, lane 2). This suggested that carbonylated DBP is found in human serum as recently described for rat serum [55]. To investigate whether carbonylated DBP is found in human serum we immunoprecipitated DBP from freshly drawn human blood and either derivatized it with 2,4-dinitrophenyl hydrazine to detect carbonylated DBP or left it untreated before Western blot analysis with anti-DNP antibodies. We found that carbonylated DBP is found in human serum (Figure 6D).

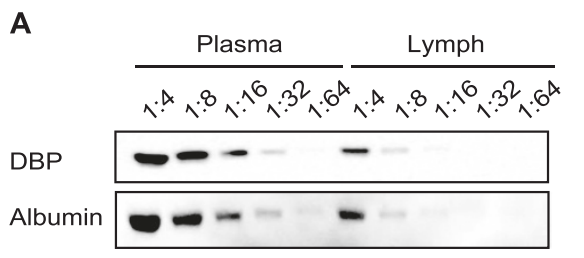

C

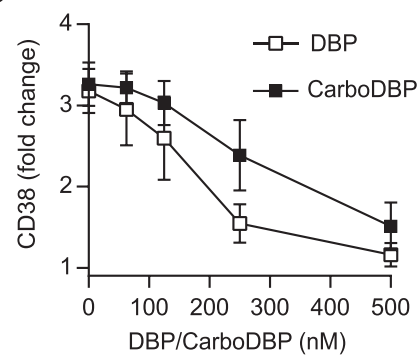

B

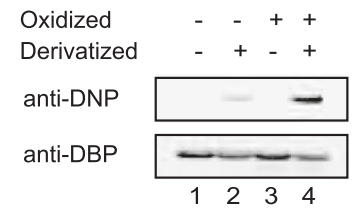

D

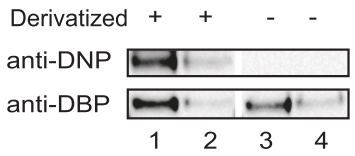

Figure 6 DBP carbonylation impedes DBP-mediated inhibition of 25(OH)D3-induced CD38 expression. (A) Western blot of DBP and albumin in serial dilutions of plasma and central lymph. (B) Western blot of non-oxidized (lanes 1 and 2) and oxidized (lanes 3 and 4) DBP that subsequently had been derivatized with 2,4-dinitrophenyl hydrazine to detect carbonyl groups (lanes 2 and 4) or left untreated (lanes 1 and 3). The membranes were first analysed with anti-DNP antibodies to detect carbonylated DBP. Subsequently, the membranes were stripped and re-blotted with anti-DBP antibodies to detect total DBP. (C) Relative CD38 cell surface expression on $T$ cells activated in the presence of $25(\mathrm{OH}) \mathrm{D}_{3}$ $(100 \mathrm{nM})$ and the indicated concentrations of DBP or carbonylated DBP (CarboDBP). Mean values \pm SEM from 3 independent experiments are plotted. (D) Representative Western blot analysis of carbonylated DBP and total DBP (loading control) in human serum. Precipitated DBP was either derivatized with 2,4-dinitrophenyl hydrazine to detect carbonyl groups (lanes 1 and 2) or left untreated (lanes 3 and 4). Lanes 1 and 3 present precipitated DBP diluted 1:4, and lanes 2 and 4 present precipitated DBP diluted 1:8. 


\section{Discussion}

This study shows that activated human $\mathrm{CD}^{+} \mathrm{T}$ cells express CYP27B1 and produce sufficient amounts of 1,25 $(\mathrm{OH})_{2} \mathrm{D}_{3}$ to affect vitamin D-responsive genes when cultured in the presence of physiological concentrations of $25(\mathrm{OH}) \mathrm{D}_{3}$ in $\mathrm{DBP} /$ serum-free medium.

We found that CYP27B1 expression becomes strongly up-regulated in activated $\mathrm{CD}_{4}^{+} \mathrm{T}$ cells (Figure 1A), and our results thereby confirm and extend previous reports on CYP27B1 expression in T cells $[20,21,28,29]$. However, although activated T cells express CYP27B1, is has been discussed whether they actually have the ability to convert $25(\mathrm{OH}) \mathrm{D}_{3}$ to $1,25(\mathrm{OH})_{2} \mathrm{D}_{3}$. Thus, some studies have found that activated $\mathrm{T}$ cells can convert $25(\mathrm{OH}) \mathrm{D}_{3}$ to $1,25(\mathrm{OH})_{2} \mathrm{D}_{3}[21,27,28]$, whereas a recent study found that $\mathrm{T}$ cells do not have this ability [20]. By measuring $1,25(\mathrm{OH})_{2} \mathrm{D}_{3}$ in the medium of $\mathrm{T}$ cells activated in the presence of $25(\mathrm{OH}) \mathrm{D}_{3}$ we found that CYP27B1 expressed by the $\mathrm{T}$ cells is functional, and that $\mathrm{T}$ cells have the ability to produce significant amounts of $1,25(\mathrm{OH})_{2} \mathrm{D}_{3}$ (Figure 1B). When determining the capacity of $\mathrm{T}$ cells to convert $25(\mathrm{OH}) \mathrm{D}_{3}$ to $1,25(\mathrm{OH})_{2} \mathrm{D}_{3}$ the kinetics of CYP27B1 expression is important to take into account. We and others [28] found that $1,25(\mathrm{OH})_{2} \mathrm{D}_{3}$ production is very low 24 hours after $\mathrm{T}$ cell activation but that it strongly increases 48 hours after activation. We find it plausible that the missing detection of $1,25(\mathrm{OH})_{2} \mathrm{D}_{3}$ produced by activated $\mathrm{T}$ cells in the study by Jeffery et al. [20] was due to the fact that the authors measured $1,25(\mathrm{OH})_{2} \mathrm{D}_{3}$ production after only 24 hours of activation. Thus, our study clarifies that activated human $\mathrm{CD} 4^{+} \mathrm{T}$ cells have the capacity to convert $25(\mathrm{OH}) \mathrm{D}_{3}$ to $1,25(\mathrm{OH})_{2} \mathrm{D}_{3}$. Furthermore, we demonstrated that activated $\mathrm{T}$ cells have the capacity to produce significantly high amounts of $1,25(\mathrm{OH})_{2} \mathrm{D}_{3}$ to affect vitamin D-responsive genes such as CD38 [35], CTLA-4 [7,20], PLC- $\gamma 1$ [25,36], IL-13 [37] and IFN- $\gamma$ [7] (Figures 2 and 3).

Despite the ability of activated T cells to convert $25(\mathrm{OH})$ $\mathrm{D}_{3}$ to $1,25(\mathrm{OH})_{2} \mathrm{D}_{3}$, addition of DBP to the medium inhibited the effect of $25(\mathrm{OH}) \mathrm{D}_{3}$ on vitamin D-responsive genes in a dose-dependent manner (Figures 2, 3, 4). Interestingly, DBP did not seem to significantly inhibit 1,25 $(\mathrm{OH})_{2} \mathrm{D}_{3}$-induced $\mathrm{T}$ cell responses (Figure 4 ). The affinity of DBP for $25(\mathrm{OH}) \mathrm{D}_{3}$ is significantly higher than for 1,25 $(\mathrm{OH})_{2} \mathrm{D}_{3}$ with a $\mathrm{K}_{\mathrm{d}}$ of $1.4 \mathrm{nM}$ and $25 \mathrm{nM}$, respectively $[30,31]$, and this could be one of the reasons that DBP sequestered $25(\mathrm{OH}) \mathrm{D}_{3}$ more efficiently than $1,25(\mathrm{OH})_{2} \mathrm{D}_{3}$. Megalin-mediated endocytosis of DBP facilitates uptake and conversion of $25(\mathrm{OH}) \mathrm{D}_{3}$ to $1,25(\mathrm{OH})_{2} \mathrm{D}_{3}$ in some types of cells such as renal proximal tubule cells and mammary epithelial cells $[39,40]$. We found that activated T cells express megalin and take up DBP. However, they do not take up DBP by megalin-mediated endocytosis as demonstrated by the lack of effect of RAP, blocking anti- megalin antibodies and competition experiments (Figure 4 and Additional file 2: Figure S2). In line with this, previous studies have demonstrated that megalin-mediated endocytosis of DBP is dependent of the co-expression of cubilin [38], and we found that cubilin expression was very low in naïve $T$ cells and that it was not up-regulated following $\mathrm{T}$ cell activation. Interestingly, we found that EIPA, which inhibits macropinocytosis, reduced the DBP uptake. Thus, activated T cells take up DBP, but this up-take is not mediated by megalin-mediated endocytosis but most likely by macropinocytosis. In contrast to megalinmediated endocytosis that promotes the conversion of 25 $(\mathrm{OH}) \mathrm{D}_{3}$ to $1,25(\mathrm{OH})_{2} \mathrm{D}_{3}$ in kidney and mammary cells $[39,40]$, macropinocytosis of $25(\mathrm{OH}) \mathrm{D}_{3}$-DBP did not deliver $25(\mathrm{OH}) \mathrm{D}_{3}$ for subsequent conversion to $1,25(\mathrm{OH})$ ${ }_{2} \mathrm{D}_{3}$ in T cells. Similar results have been found for monocytes that also take up DBP by a megalin-independent mechanism and where DBP inhibits the conversion of 25 $(\mathrm{OH}) \mathrm{D}_{3}$ to $1,25(\mathrm{OH})_{2} \mathrm{D}_{3}$ [33].

By titrations of $25(\mathrm{OH}) \mathrm{D}_{3}$ and $1,25(\mathrm{OH})_{2} \mathrm{D}_{3}$ in serumfree medium, we found that maximal effect on vitamin D-regulated genes was obtained at 100 and $10 \mathrm{nM}$, respectively, as assessed by CD38 expression (Figure 2A). Addition of serum or purified DBP considerably shifted the concentration of $25(\mathrm{OH}) \mathrm{D}_{3}$ but not of $1,25(\mathrm{OH})_{2} \mathrm{D}_{3}$ required to affect vitamin D-responsive genes (Figure 2B). These results support that the physiological concentration of $1,25(\mathrm{OH})_{2} \mathrm{D}_{3}(60-110 \mathrm{pM})$ is not sufficiently high to affect $\mathrm{T}$ cell responses, and that a significant local production of $1,25(\mathrm{OH})_{2} \mathrm{D}_{3}$ is essential to reach concentration $(>1000 \mathrm{pM})$ required to affect $\mathrm{T}$ cells as previously suggested [20]. Furthermore, these results indicate that mechanisms must exist whereby $25(\mathrm{OH}) \mathrm{D}_{3}$ is released from DBP and becomes available for the conversion to 1,25 $(\mathrm{OH})_{2} \mathrm{D}_{3}$, given that $25(\mathrm{OH}) \mathrm{D}_{3}$ affects $\mathrm{T}$ cell responses in vivo. In a search for such mechanisms, we investigated whether actin, arachidonic acid or albumin affected the sequestration of $25(\mathrm{OH}) \mathrm{D}_{3}$ by DBP, as DBP can bind actin $[46,47]$ and fatty acids $[48,49]$, and such binding might affect the affinity of $\mathrm{DBP}$ for $25(\mathrm{OH}) \mathrm{D}_{3}[48,49]$. However, neither actin, arachidonic acid nor albumin affected the DBP-mediated inhibition of $25(\mathrm{OH}) \mathrm{D}_{3}$-induced $\mathrm{T}$ cell responses (Figure 5). Local concentrations and/or modifications of DBP might also affect the availability of $25(\mathrm{OH})$ $\mathrm{D}_{3}$ to $\mathrm{T}$ cells. Inflammation-induced oxidative stress can result in oxidative modifications of proteins leading to protein carbonylation [54-56]. Protein carbonylation is irreversible and leads to disturbances in protein conformation and function [54]. Interestingly, we found evidence that carbonylation of DBP impedes DBP-mediated inhibition of $25(\mathrm{OH}) \mathrm{D}_{3}$-induced $\mathrm{T}$ cell responses (Figure 6). Thus, inflammation-induced oxidative stress could locally lead to DBP carbonylation and thereby to a higher concentration of free $25(\mathrm{OH}) \mathrm{D}_{3}$. Finally, the $\mathrm{DBP}$ gene is 
polymorphic, and the three most common DBP isotypes termed GC1S, GC1F and GC2 have varying affinities for $25(\mathrm{OH}) \mathrm{D}_{3}$, which might also influence the availability and conversion of $25(\mathrm{OH}) \mathrm{D}_{3}$ to $1,25(\mathrm{OH})_{2} \mathrm{D}_{3}$ and thereby the efficiency of $25(\mathrm{OH}) \mathrm{D}_{3}$-induced $\mathrm{T}$ cell responses [20,58].

Experiments by nature indicate that significant amounts of $1,25(\mathrm{OH})_{2} \mathrm{D}_{3}$ actually can be produced locally by the involved immune cells during inflammation/infection in vivo. Thus, elevated systemic levels of $1,25(\mathrm{OH})_{2} \mathrm{D}_{3}$ can be observed in patients with granulomatous diseases such as sarcoidosis and tuberculosis [24]. The granulomas are characterized by a central area of activated macrophages surrounded by activated $\mathrm{CD} 4^{+} \mathrm{T}$ cells. This suggests that interactions between activated $\mathrm{T}$ cells and macrophages might induce mechanisms that allow efficient conversion of $25(\mathrm{OH}) \mathrm{D}_{3}$ to $1,25(\mathrm{OH})_{2} \mathrm{D}_{3}$ in vivo despite the presence of DBP. This is in good accordance with previous studies which found that treatment of macrophages with IFN- $\gamma$ or soluble CD40L increases their expression of CYP27B1 and their capacity to convert 25 $(\mathrm{OH}) \mathrm{D}_{3}$ to $1,25(\mathrm{OH})_{2} \mathrm{D}_{3}$ [59-61]. Thus, whether vitamin $\mathrm{D}$ actually affects a given $\mathrm{T}$ cell response in vivo probably relies on a mixture of factors in addition to the concentration of $25(\mathrm{OH}) \mathrm{D}_{3}$ such as the isotype, local concentration and degradation rate of DBP and the expression levels of CYP27B1, the VDR and the $1,25(\mathrm{OH})_{2} \mathrm{D}_{3}$-24-hydroxylase CYP24A1 of the cells locally involved in the immune response.

\section{Conclusions}

In summary, activated $\mathrm{T}$ cells express CYP27B1 and can convert $25(\mathrm{OH}) \mathrm{D}_{3}$ to $1,25(\mathrm{OH})_{2} \mathrm{D}_{3}$ in sufficiently high concentrations to affect vitamin D-responsive genes when cultured in serum-free medium. However, DBP sequesters $25(\mathrm{OH}) \mathrm{D}_{3}$ and inhibits the production of $1,25(\mathrm{OH})_{2} \mathrm{D}_{3}$ in $\mathrm{T}$ cells. To fully exploit the immune-regulatory potential of vitamin $\mathrm{D}$, further studies of the mechanisms that enable the immune system to exploit $25(\mathrm{OH}) \mathrm{D}_{3}$ and convert it to $1,25(\mathrm{OH})_{2} \mathrm{D}_{3}$ are required.

\section{Methods}

\section{Chemicals}

$25(\mathrm{OH}) \mathrm{D}_{3}$ (BML-DM100-0001) and 1,25(OH) ${ }_{2} \mathrm{D}_{3}$ (BMLDM200-0050) were from Enzo Life Sciences, Inc., Ann Arbor, MI. Stock solutions of $2.5 \mathrm{mM} 25(\mathrm{OH}) \mathrm{D}_{3}$ and $2.4 \mathrm{mM} 1,25(\mathrm{OH})_{2} \mathrm{D}_{3}$ were prepared in anhydrous $(\geq 99.5 \%)$ ethanol and stored at $-80^{\circ} \mathrm{C}$. To determine $1,25(\mathrm{OH})$ ${ }_{2} \mathrm{D}_{3}$ in the medium we used the 1,25 -Dihydroxy Vitamin D EIA kit (AC-62F1) from IDS, Tyne and Wear, UK according to the manufacturer's instructions. DBP $(\mathrm{A} 50674 \mathrm{H})$ and albumin (A8763) purified from human serum were from Meridian Life Sciences and SigmaAldrich, respectively. Actin (A2522), arachidonic acid (A9673) and ketoconazole (K1003) were from Sigma-
Aldrich. Serum and central lymph from mini-pigs were provided by the Department for Experimental Medicine, University of Copenhagen, Denmark.

\section{Cell culture}

Mononuclear cells from blood were isolated by Lymphoprep (Axis-Shield, Oslo, Norway) density gradient centrifugation from healthy donors after obtaining informed, written consent in accordance with the Declarations of Helsinki principles for research involving human objects. The study was approved by the local Ethics Committee (H-3-2009-132, The Committees of Biomedical Research Ethics for the Capital Region in Denmark). Naïve CD4 ${ }^{+}$ T cells were isolated, cultured and activated as previously described [27]. The cells were activated for 3 days in serum-free X-VIVO 15 medium (1041, Lonza, Verviers, Belgium) if not otherwise stated.

\section{Flow cytometry}

For flow cytometry analyses of CD38 and TCR expression the cells were stained with anti-CD38-APC (HIT2) or anti-CD3e-PE (UCHT1) both from BD Biosciences and analyzed on a FACS Calibur. Fold change in CD38 surface expression was calculated as mean CD38 fluorescence intensity of cells stimulated in the presence of 25 $(\mathrm{OH}) \mathrm{D}_{3} / 1,25(\mathrm{OH})_{2} \mathrm{D}_{3}$ divided with mean CD38 fluorescence intensity of cells stimulated in the absence of 25 $(\mathrm{OH}) \mathrm{D}_{3} / 1,25(\mathrm{OH})_{2} \mathrm{D}_{3}$. Percent TCR surface expression was calculated as (mean fluorescence intensity of stimulated cells divided with mean fluorescence intensity of untreated cells) $\times 100 \%$.

\section{Western blot and ELISA}

Western blot analyses were performed as previously described [27,62]. Following incubation with primary antibody, the membranes were washed, and the proteins visualized following $60 \mathrm{~min}$ incubation at room temperature with HRP-conjugated rabbit anti-mouse Ig, swine anti-rabbit Ig or rabbit anti-goat Ig (P0260, P0399 and P0449 DAKO, Glostrup, Denmark) using ECL (Amersham Biosciences) technology. The primary antibodies used were anti-VDR, anti-CD3 , anti-CTLA-4 and anti-albumin (D-6, 6B10.2, C-19 and F-8, Santa Cruz Biotecnology), anti-PLC- $\gamma 1$ (05-163, Upstate Biotechnology), anti-ezrin (3145, Cell Signaling Technology) and anti-DBP (SAB2501100, Sigma Aldrich). For band density quantification ECL exposed sheets were analysed in a ChemiDoc MP Imaging System from Bio-Rad. Measurement of the cytokines IL-13 and IFN- $\gamma$ were determined by ELISA according to the manufacturer's protocol (Ready-Set-Go; eBioscience). 


\section{Real-time RT-PCR}

mRNA for CYP27B1, CD38, IL-13, IFN- $\gamma$, megalin, cubilin, GAPDH and RPLP0 were measured by real-time RTPCR as previously described [27]. Primers used (sense/ antisense primer) were:

CYP27B1: (AAGCGCAGCTGTATGGGGAGAC/GCT CAGGCTGCACCTCAAAATG),

CD38: (CTGGAGAAAGGACTGCAGCAACAA/GCA

TCACATGGACCACATCACA),

IL-13: (GATTCTGCCCGCACAAGGTCTC/GTAAGA

GCAGGTCCTTTACAAACTGGG),

IFN- $\gamma:$ (CAGCTCTGCATCGTTTTGGGTTC/CCATT

ATCCGCTACATCTGAATGACCT)

Megalin: (CATGAGGTGTGCAATGGTGTGG/TCTG

TACAAGGTTTAGGGGTCGGTT).

Cubilin: (GGTCCTCTTGACTTTTGTGTCCTTCC/C ATCGTTGACACAGCTTCCCGT).

GAPDH: (CCTCCTGCACCACCAACTGCTT/GAGG GGCCATCCACAGTCTTCT).

RPLP0; (GGAAACTCTGCATTCTCGCTTCCT/CCA GGACTCGTTTGTACCCGTTG).

The data were normalized to number of cells by calculation from the total RNA yield per cell in each sample (the raw data represents number of target cDNA molecules measured per $12.5 \mathrm{ng}$ total RNA).

\section{DBP uptake and TCR internalization}

For studies of cellular uptake of DBP purified DBP was conjugated with Alexa Fluor 488 (AF488) using a commercial kit (A10235, Molecular Probes). $120 \mathrm{nM}$ DBP-AF488 was added to cell cultures of $1 \times 10^{6}$ cells $/ \mathrm{ml}$ $\mathrm{X}$-VIVO 15 for $12 \mathrm{~h}$ at $37^{\circ} \mathrm{C}$. The cells were subsequently washed and analyzed by flow cytometry. Samples incubated with $120 \mathrm{nM}$ non-conjugated DBP were included as controls. In some studies the cells were activated for 3 days, washed and resuspended in X-VIVO 15 including 120 nM DBP-AF488 and either $1 \mu \mathrm{M}$ RAP (Merch Millipore), $20 \mu \mathrm{g} / \mathrm{ml}$ anti-megalin blocking Ab (anti-Megalin Ab, C-19 and H-245 from Santa Cruz Biotechnology), 4 $\mu \mathrm{M}$ EGTA for calcium deprivation, 12,000 nM nonconjugated DBP to outcompete possible specific uptake of DBP-AF488 by receptor-mediated endocytosis or $50 \mu \mathrm{M}$ 5-(N-ethyl-N-isopropyl)-amiloride (EIPA) (Sigma Aldrich) an inhibitor of macropinocytosis [43]. For experiments including EIPA, DMSO was added to all samples. The cells were subsequently analysed by flow cytometry. For microscopy, cells were incubated with DBP-AF488 for $12 \mathrm{~h}$ at $37^{\circ} \mathrm{C}$ and then stained with anti-CD3 (UCHT1, BD) followed by an AlexaFluor568 coupled anti-mouse Ig and DAPI (nuclear staining). The cells were fixed in $1 \%$ paraformaldehyde and analysed by confocal microscopy (Nikon TE 2000-E). For TCR down-regulation experiments the activated cells were rested for $24 \mathrm{~h}$ after removal of the CD3/CD28 beads. Hereafter, the cells were adjusted to $1 \times 10^{6}$ cells $/ \mathrm{ml}$, pre-treated with either DMSO or $50 \mu \mathrm{M}$ EIPA dissolved in DMSO for $30 \mathrm{~min}$ and then treated with $30 \mathrm{nM}$ phorbol 12,13-dibutyrate (PDBu) (Sigma-Aldrich) for $60 \mathrm{~min}$ as previously described [63,64]. The TCR surface expression levels were subsequently determined by flow cytometry.

\section{DBP carbonylation and immunoprecipitation}

For carbonylation of DBP, $1 \mathrm{mg}$ purified DBP was oxidized in $100 \mu$ l oxidation buffer (50 mM Hepes, 100 $\mathrm{mM} \mathrm{KCl}, 10 \mathrm{mM} \mathrm{MgCl}$, pH 7.4). An additional $100 \mu \mathrm{l}$ oxidation buffer including $50 \mathrm{mM}$ ascorbic acid and 200 $\mu \mathrm{M} \mathrm{FeCl}{ }_{3}$ was added and the tube incubated for $15 \mathrm{~h}$ at $37^{\circ} \mathrm{C}$ with shaking. $1 \mathrm{mM}$ EDTA in oxidation buffer was added to stop the reaction. The solution was transferred to a VivaSpin500 column (VS0122, Sautorius Stedim Biotech) and the buffer changed to PBS (column was spun down once with PBS/1 $\mu \mathrm{M}$ EDTA and twice with PBS). To test the efficiency of the carbonylation reaction, Western blot analyses were performed comparing nonoxidized and oxidized DBP (CarboDBP) after derivatization with 2,4-dinitrophenyl hydrazine using the commercial Oxyblot Protein Oxidation Detection kit (S7150, Millipore) according to the manufacturer's instruction. To determine whether carbonylated DBP is found in human serum, we isolated DBP from freshly isolated human serum by classical immunoprecipitation $[65,66]$ using anti-DBP antibodies and protein A coated beads. The precipitated DBP was either derivatized with 2,4dinitrophenyl hydrazine or left untreated before Western blot analyses with anti-DNP antibodies to detect carbonylated DBP. The membranes were subsequently stripped and re-blotted with anti-DBP antibodies to detect total DBP.

\section{Statistical analysis}

Statistical analyses were performed using Student's $t$ test with a $5 \%$ significance level, unpaired and paired observations and equal variance.

\section{Additional files}

Additional file 1: Figure S1. Flow cytometric analysis of (A) PBMC and (B) purified naive CD4+ $T$ cells.

Additional file 2: Figure S2. T cells do not take up DBP by megalinmediated endocytosis. Flow cytometry histograms illustrating DBP-AF488 fluorescence of activated T cells incubated with $120 \mathrm{nM}$ DBP or $120 \mathrm{nM}$ DBF-AF488 in the absence or presence of (A) EGTA (4 $\mu \mathrm{M})$, (B) anti-megalin anti-body $(20 \mu \mathrm{g} / \mathrm{ml})$ or $(C)$ EGTA $(4 \mu \mathrm{M})$ plus anti-megalin antibody $(20 \mu \mathrm{g} / \mathrm{ml})$.

\section{Abbreviations}

1,25(OH) $2 \mathrm{D}_{3}$ : 1a,25-dihydroxyvitamin $\mathrm{D} 3 ; 25(\mathrm{OH}) \mathrm{D}_{3}$ : 25-hydroxyvitamin $\mathrm{D} 3$; VDR: Vitamin D receptor; DBP: Vitamin D-binding protein; APC: Antigen presenting cell; TCR: T cell receptor; FBS: Fetal bovine serum; RAP: Receptorassociated protein; EIPA: 5-(N-Ethyl-N-isopropyl)-amiloride; PDBu: Phorbol 12,13-dibutyrate. 


\section{Competing interests}

The authors declare that they have no competing interests.

\section{Authors' contributions}

MK and MRvE did most of the experiments, contributed to the planning, designing and analyses of the experiments and the writing of the manuscript. $\mathrm{TBL}, \mathrm{PS}, \mathrm{CMB}, \mathrm{AW}$ and $\mathrm{N} \varnothing$ contributed to the planning, designing and analyses of some of the experiments, and writing of the manuscript. CG conceptualized the research, directed the study, analyzed data and wrote the manuscript. All authors read and approved the final manuscript.

\section{Acknowledgements}

The expert technical help of Bodil Nielsen, Anja Jokipii and Dominique Bengtsson is gratefully acknowledged.

\section{Funding}

The Danish Medical Research Council, The Lundbeck Foundation, The Novo Nordisk Foundation and The A.P. Møller Foundation for the Advancement of Medical Sciences.

\section{Author details}

${ }^{1}$ Department of International Health, Immunology and Microbiology, Faculty of Health and Medical Sciences, University of Copenhagen, Copenhagen, Denmark. ${ }^{2}$ Department of Orthopedic Surgery M, Institute of Sports Medicine, Bispebjerg Hospital, Copenhagen, Denmark. ${ }^{3}$ Center for Healthy Aging, Faculty of Health and Medical Sciences, University of Copenhagen, Copenhagen, Denmark.

Received: 4 April 2014 Accepted: 29 August 2014

Published online: 18 September 2014

\section{References}

1. Murphy KM, Reiner SL: The lineage decisions of helper T cells. Nat Rev Immunol 2002, 2:933-944.

2. Zhu J, Yamane $H$, Paul WE: Differentiation of effector CD4 T cell populations (*). Annu Rev Immunol 2010, 28:445-489.

3. Littman DR, Rudensky AY: Th17 and regulatory T cells in mediating and restraining inflammation. Cell 2010, 140:845-858.

4. Mora JR, Iwata $M$, von Andrian UH: Vitamin effects on the immune system: vitamins A and D take centre stage. Nat Rev Immunol 2008, 8:685-698.

5. Rigby WF, Yirinec B, Oldershaw RL, Fanger MW: Comparison of the effects of 1,25-dihydroxyvitamin D3 on T lymphocyte subpopulations. Eur J Immunol 1987, 17:563-566.

6. Reichel H, Koeffler HP, Tobler A, Norman AW: 1 alpha,25-Dihydroxyvitamin D3 inhibits gamma-interferon synthesis by normal human peripheral blood lymphocytes. Proc Natl Acad Sci U S A 1987, 84:3385-3389.

7. Jeffery LE, Burke F, Mura M, Zheng Y, Qureshi OS, Hewison M, Walker LS, Lammas DA, Raza K, Sansom DM: 1,25-Dihydroxyvitamin D3 and IL-2 combine to inhibit $\mathrm{T}$ cell production of inflammatory cytokines and promote development of regulatory T cells expressing CTLA-4 and FoxP3. J Immunol 2009, 183:5458-5467.

8. Thien R, Baier K, Pietschmann P, Peterlik M, Willheim M: Interactions of 1 alpha,25-dihydroxyvitamin D3 with IL-12 and IL-4 on cytokine expression of human T Iymphocytes. J Allergy Clin Immunol 2005, 116:683-689.

9. van Etten E, Mathieu C: Immunoregulation by 1,25-dihydroxyvitamin D3: basic concepts. J Steroid Biochem Mol Biol 2005, 97:93-101.

10. Palmer MT, Lee YK, Maynard CL, Oliver JR, Bikle DD, Jetten AM, Weaver CT: Lineage-specific effects of 1,25-dihydroxyvitamin $\mathrm{D}(3)$ on the development of effector CD4 T cells. J Biol Chem 2011, 286:997-1004.

11. Joshi S, Pantalena LC, Liu XK, Gaffen SL, Liu H, Rohowsky-Kochan C, Ichiyama K, Yoshimura A, Steinman L, Christakos S, Youssef S: 1,25-dihydroxyvitamin $\mathrm{D}$ (3) ameliorates Th17 autoimmunity via transcriptional modulation of interleukin-17A. Mol Cell Biol 2011, 31:3653-3669.

12. Urry Z, Chambers ES, Xystrakis E, Dimeloe S, Richards DF, Gabrysova L, Christensen J, Gupta A, Saglani S, Bush A, O'Garra A, Brown Z, Hawrylowicz CM: The role of 1alpha,25-dihydroxyvitamin D3 and cytokines in the promotion of distinct Foxp3+ and IL-10+ CD4+ T cells. Eur J Immunol 2012, 42:2697-2708.
13. Hypponen E, Laara E, Reunanen A, Jarvelin MR, Virtanen SM: Intake of vitamin D and risk of type 1 diabetes: a birth-cohort study. Lancet 2001, 358:1500-1503.

14. Amital H, Szekanecz Z, Szucs G, Danko K, Nagy E, Csepany T, Kiss E, Rovensky J, Tuchynova A, Kozakova D, Doria A, Corocher N, Agmon-Levin N, Barak V, Orbach H, Zandman-Goddard G, Shoenfeld Y: Serum concentrations of $25-\mathrm{OH}$ vitamin $\mathrm{D}$ in patients with systemic lupus erythematosus (SLE) are inversely related to disease activity: is it time to routinely supplement patients with SLE with vitamin D? Ann Rheum Dis 2010, 69:1155-1157.

15. Ascherio A, Munger $\mathrm{KL}$, Simon $\mathrm{KC}$ : Vitamin $\mathrm{D}$ and multiple sclerosis. Lancet Neurol 2010, 9:599-612.

16. Pierrot-Deseilligny C, Souberbielle JC: Contribution of vitamin D insufficiency to the pathogenesis of multiple sclerosis. Ther Adv Neurol Disord 2013, 6:81-116.

17. Feldman D, Pike JW, Glowacki J: Vitamin D. 3rd edition. Burlington: Elsevier Academic Press; 2011.

18. Joseph RW, Bayraktar UD, Kim TK, St John LS, Popat U, Khalili J, Molldrem JJ, Wieder ED, Komanduri KV: Vitamin D receptor upregulation in alloreactive human T cells. Hum Immunol 2012, 73:693-698.

19. Lemire JM, Ince A, Takashima M: 1,25-Dihydroxyvitamin D3 attenuates the expression of experimental murine lupus of MRL/I mice. Autoimmunity 1992, 12:143-148.

20. Jeffery LE, Wood AM, Qureshi OS, Hou TZ, Gardner D, Briggs Z, Kaur S, Raza K, Sansom DM: Availability of 25 -hydroxyvitamin D(3) to APCs controls the balance between regulatory and inflammatory $T$ cell responses. J Immunol 2012, 189:5155-5164.

21. Sigmundsdottir H, Pan J, Debes GF, Alt C, Habtezion A, Soler D, Butcher EC DCs metabolize sunlight-induced vitamin D3 to 'program' T cell attraction to the epidermal chemokine CCL27. Nat Immunol 2007, 8:285-293.

22. Liu PT, Stenger S, Li H, Wenzel L, Tan BH, Krutzik SR, Ochoa MT, Schauber J, Wu K, Meinken C, Kamen DL, Wagner M, Bals R, Steinmeyer A, Zugel U, Gallo RL, Eisenberg D, Hewison M, Hollis BW, Adams JS, Bloom BR, Modlin $\mathrm{RL}$ : Toll-like receptor triggering of a vitamin D-mediated human antimicrobial response. Science 2006, 311:1770-1773.

23. Adams JS, Ren S, Liu PT, Chun RF, Lagishetty V, Gombart AF, Borregaard N, Modlin RL, Hewison M: Vitamin D-directed rheostatic regulation of monocyte antibacterial responses. J Immunol 2009, 182:4289-4295.

24. Jacobs TP, Bilezikian JP: Clinical review: rare causes of hypercalcemia. J Clin Endocrinol Metab 2005, 90:6316-6322.

25. von Essen MR, Kongsbak M, Schjerling P, Olgaard K, Odum N, Geisler C: Vitamin $\mathrm{D}$ controls $\mathrm{T}$ cell antigen receptor signaling and activation of human T cells. Nat Immunol 2010, 11:344-349.

26. Kongsbak M, Levring TB, Geisler C, von Essen MR: The vitamin D receptor and T cell function. Front Immunol 2013, 4:1-10

27. Kongsbak M, von Essen MR, Boding L, Levring TB, Schjerling P, Lauritsen JP, Woetmann A, Odum N, Bonefeld CM, Geisler C: Vitamin D up-regulates the vitamin $D$ receptor by protecting it from proteasomal degradation in human CD4+ T cells. PLoS One 2014, 9:e96695.

28. Correale J, Ysrraelit MC, Gaitan MI: Immunomodulatory effects of vitamin D in multiple sclerosis. Brain 2009, 132:1146-1160.

29. Baeke F, Korf H, Overbergh L, van EE, Verstuyf A, Gysemans C, Mathieu C: Human T lymphocytes are direct targets of 1,25-dihydroxyvitamin $D(3)$ in the immune system. J Steroid Biochem Mol Biol 2010, 121:221-227.

30. Bikle DD, Siiteri PK, Ryzen E, Haddad JG: Serum protein binding of 1,25-dihydroxyvitamin D: a reevaluation by direct measurement of free metabolite levels. J Clin Endocrinol Metab 1985, 61:969-975.

31. Bikle DD, Gee E, Halloran B, Kowalski MA, Ryzen E, Haddad JG: Assessment of the free fraction of 25 -hydroxyvitamin $D$ in serum and its regulation by albumin and the vitamin D-binding protein. J Clin Endocrinol Metab 1986, 63:954-959.

32. Safadi FF, Thornton P, Magiera H, Hollis BW, Gentile M, Haddad JG, Liebhaber SA, Cooke NE: Osteopathy and resistance to vitamin D toxicity in mice null for vitamin D binding protein. J Clin Invest 1999, 103:239-251.

33. Chun RF, Lauridsen AL, Suon L, Zella LA, Pike JW, Modlin RL, Martineau AR, Wilkinson RJ, Adams J, Hewison M: Vitamin D-binding protein directs monocyte responses to 25-hydroxy- and 1,25-dihydroxyvitamin D. J Clin Endocrinol Metab 2010, 95:3368-3376.

34. Bikle DD, Gee E: Free, and not total, 1,25-dihydroxyvitamin D regulates 25-hydroxyvitamin D metabolism by keratinocytes. Endocrinology 1989, 124:649-654. 
35. Stoeckler JD, Stoeckler HA, Kouttab N, Maizel AL: 1alpha,25-Dihydroxyvitamin D3 modulates CD38 expression on human lymphocytes. J Immunol 1996, 157:4908-4917.

36. Pillai S, Bikle DD, Su MJ, Ratnam A, Abe J: 1,25-Dihydroxyvitamin D3 upregulates the phosphatidylinositol signaling pathway in human keratinocytes by increasing phospholipase C levels. J Clin Invest 1995, 96:602-609

37. Matheu V, Back O, Mondoc E, Issazadeh-Navikas S: Dual effects of vitamin D-induced alteration of $\mathrm{TH} 1 / \mathrm{TH} 2$ cytokine expression: enhancing lgE production and decreasing airway eosinophilia in murine allergic airway disease. J Allergy Clin Immunol 2003, 112:585-592.

38. Nykjaer A, Fyfe JC, Kozyraki R, Leheste JR, Jacobsen C, Nielsen MS, Verroust PJ, Aminoff M, de la Chapelle A, Moestrup SK, Ray R, Gliemann J, Willnow $\mathrm{TE}$, Christensen El: Cubilin dysfunction causes abnormal metabolism of the steroid hormone 25(OH) vitamin D(3). Proc Natl Acad Sci U S A 2001, 98:13895-13900

39. Nykjaer A, Dragun D, Walther D, Vorum H, Jacobsen C, Herz J, Melsen F, Christensen El, Willnow TE: An endocytic pathway essential for renal uptake and activation of the steroid 25-(OH) vitamin D3. Cell 1999, 96:507-515.

40. Rowling MJ, Kemmis CM, Taffany DA, Welsh J: Megalin-mediated endocytosis of vitamin $\mathrm{D}$ binding protein correlates with 25 hydroxycholecalciferol actions in human mammary cells. J Nutr 2006, 136:2754-2759.

41. Machii T, Kimura H, Ueda E, Chujo T, Morita T, Katagiri S, Tagawa S, Kitani T: Distribution of Gc protein (vitamin D binding protein) on the surfaces of normal human lymphocytes and leukemic lymphocytes. Acta Haematol 1986, 75:26-29.

42. Kerr MC, Teasdale RD: Defining macropinocytosis. Traffic 2009, 10:364-371.

43. Koivusalo M, Welch C, Hayashi H, Scott CC, Kim M, Alexander T, Touret N, Hahn KM, Grinstein S: Amiloride inhibits macropinocytosis by lowering submembranous $\mathrm{pH}$ and preventing Rac1 and Cdc42 signaling. J Cell Biol 2010, 188:547-563

44. Menné C, Sorensen T, Siersma V, von Essen M, Odum N, Geisler C: Endo- and exocytic rate constants for spontaneous and protein kinase C-activated T cell receptor cycling. Eur J Immunol 2002, 32:616-626.

45. Dietrich J, Menne C, Lauritsen JP, von Essen M, Rasmussen AB, Odum N, Geisler C: Ligand-induced TCR down-regulation is not dependent on constitutive TCR cycling. J Immunol 2002, 168:5434-5440.

46. Van Baelen H, Bouillon R, De Moor P: Vitamin D-binding protein (Gc-globulin) binds actin. J Biol Chem 1980, 255:2270-2272

47. Otterbein LR, Cosio C, Graceffa P, Dominguez R: Crystal structures of the vitamin D-binding protein and its complex with actin: structural basis of the actin-scavenger system. Proc Natl Acad Sci U S A 2002, 99:8003-8008.

48. Bouillon R, Xiang DZ, Convents R, Van Baelen H: Polyunsaturated fatty acids decrease the apparent affinity of vitamin $D$ metabolites for human vitamin D-binding protein. J Steroid Biochem Mol Biol 1992, 42:855-861.

49. Calvo M, Ena JM: Relations between vitamin $D$ and fatty acid binding properties of vitamin D-binding protein. Biochem Biophys Res Commun 1989, 163:14-17

50. Chun RF, Peercy BE, Adams JS, Hewison M: Vitamin D binding protein and monocyte response to 25-hydroxyvitamin $D$ and 1,25-dihydroxyvitamin D: analysis by mathematical modeling. PLoS One 2012, 7:e30773.

51. Chun RF, Peercy BE, Orwoll ES, Nielson CM, Adams JS, Hewison M: Vitamin D and DBP: the free hormone hypothesis revisited. J Steroid Biochem Mol Biol 2013. doi: 10.1016/j.jsbmb.2013.09.012.

52. Stead EA, Warren JV: The protein content of the extracellular fluid in normal subjects after venous congestion and in patients with cardiac failure, anoxemia, and fever. J Clin Invest 1944, 23:283-287.

53. Witte $\mathrm{CL}$, Witte $M$ H, Dumont $A E$, Cole WR, Smith JR: Protein content in lymph and edema fluid in congestive heart failure. Circulation 1969, 40:623-630.

54. Nystrom T: Role of oxidative carbonylation in protein quality control and senescence. EMBO J 2005, 24:1311-1317.

55. Wen JJ, Garg NJ: Proteome expression and carbonylation changes during Trypanosoma cruzi infection and Chagas disease in rats. Mol Cell Proteomics 2012, 11:M111.

56. Soundaravally R, Pukazhvandthen P, Zachariah B, Hamide A: Plasma ferritin and indices of oxidative stress in Helicobacter pylori infection among schoolchildren. J Pediatr Gastroenterol Nutr 2013, 56:519-522.
57. Thanan R, Oikawa S, Yongvanit P, Hiraku Y, Ma N, Pinlaor S, Pairojkul C, Wongkham C, Sripa B, Khuntikeo N, Kawanishi S, Murata M: Inflammationinduced protein carbonylation contributes to poor prognosis for cholangiocarcinoma. Free Radic Biol Med 2012, 52:1465-1472.

58. Arnaud J, Constans J: Affinity differences for vitamin D metabolites associated with the genetic isoforms of the human serum carrier protein (DBP). Hum Genet 1993, 92:183-188.

59. Klug-Micu GM, Stenger S, Sommer A, Liu PT, Krutzik SR, Modlin RL, Fabri M: CD40 ligand and interferon-gamma induce an antimicrobial response against Mycobacterium tuberculosis in human monocytes. Immunology 2013, 139:121-128.

60. Fabri M, Stenger S, Shin DM, Yuk JM, Liu PT, Realegeno S, Lee HM, Krutzik SR, Schenk M, Sieling PA, Teles R, Montoya D, lyer SS, Bruns H, Lewinsohn DM, Hollis BW, Hewison M, Adams JS, Steinmeyer A, Zugel U, Cheng G, Jo EK, Bloom BR, Modlin RL: Vitamin D is required for IFN-gamma-mediated antimicrobial activity of human macrophages. Sci Trans/ Med 2011 3:104ra102.

61. Edfeldt K, Liu PT, Chun R, Fabri M, Schenk M, Wheelwright M, Keegan C, Krutzik SR, Adams JS, Hewison M, Modlin RL: T-cell cytokines differentially control human monocyte antimicrobial responses by regulating vitamin D metabolism. Proc Natl Acad Sci U S A 2010, 107:22593-22598.

62. Nielsen M, Svejgaard A, Skov S, Dobson P, Bendtzen K, Geisler C, Odum N: IL-2 induces beta2-integrin adhesion via a wortmannin/LY294002-sensitive, rapamycin-resistant pathway. Phosphorylation of a 125-kilodalton protein correlates with induction of adhesion, but not mitogenesis. J Immunol 1996, 157:5350-5358.

63. Dietrich J, Geisler C: T cell receptor zeta allows stable expression of receptors containing the CD3y leucine-based receptor-sorting motif. J Biol Chem 1998, 273:26281-26284.

64. von Essen M, Nielsen MW, Bonefeld CM, Boding L, Larsen JM, Leitges M, Baier G, Odum N, Geisler C: Protein kinase C (PKC)a and PKC $\theta$ are the major PKC isotypes involved in TCR down-regulation. J Immunol 2006 176:7502-7510.

65. Geisler C, Schøller J, Wahi MA, Rubin B, Weiss A: Association of the human CD3- $\zeta$ chain with the aß-T cell receptor/CD3 complex. J Immunol 1990, 145:1761-1767.

66. Geisler C, Rubin B, Caspar-Bauguil S, Champagne E, Vangsted A, Hou X, Gajhede M: Structural mutations of C-domains in members of the immunoglobulin superfamily: consequences for the interactions between the T cell antigen receptor and the $\zeta_{2}$ homodimer. J Immunol 1992, 148:3469-3477.

\section{doi:10.1186/s12865-014-0035-2}

Cite this article as: Kongsbak et al:: Vitamin D-binding protein controls T cell responses to vitamin D. BMC Immunology 2014 15:35.

\section{Submit your next manuscript to BioMed Central and take full advantage of:}

- Convenient online submission

- Thorough peer review

- No space constraints or color figure charges

- Immediate publication on acceptance

- Inclusion in PubMed, CAS, Scopus and Google Scholar

- Research which is freely available for redistribution 